\title{
ANALISIS MOTIVASI SISWA MTS BADRUSSALAM TERHADAP KEGIATAN EKSTRAKURIKULER OLAHRAGA HOKCKEY
}

\author{
Sunanto, Mohammad Taufiq \\ Universitas Nahdlatul Ulama Surabaya \\ e-mail:sunanto68@yahoo.com
}

\begin{abstract}
Abstrak: Kegiatan ekstrakurikuler hockey merupakan kegiatan yang dilakukan di luar jam sekolah yang disediakan sekolah bagi para siswa kegiatan permainan hockey. Setiap pasukan akan coba menjaringkan gol dengan menggunakan sebatang kayu yang bengkok atau berlekuk di ujung pemukul untuk mengarahkan sebiji bola yang keras ke dalam gol lawan. Tujuan penelitian ini adalah untuk mengetahui motivasi siswa MTs. Badrussalam Surabaya terhadap kegiatan ekstrakurikuler olahraga hockey. Manfaat penelitian adalah dapat menambahkan pengetahuan tentang motivasi siswa MTs. Badrussalam Surabaya terhadap kegiatan ekstrakurikuler olahraga hockey. Jenis Penelitian ini menggunakan deskripsi kualitatif. Subjek penelitian adalah kepala sekolah, waka kesiswaan, guru BP, guru penjas, dan 40 siswa MTs. Badrussalam Surabaya. Teknik pengumpulan data penelitian ini adalah observasi dengan wawancara dan dokumentasi. Hasil penelitian ini adalah bahwa motivasi siswa MTs. Badrussalam Surabaya dalam mengikuti ekstrakurikuler olahraga hockey adalah minat siswa, motivasi siswa, kedisiplinan siswa dan semangat siswa untuk mengikuti ekstrakurikuler olahraga hockey serta dukungan dari pihak sekolah.
\end{abstract}

Kata Kunci: ekstrakurikuler olahraga hockey, motivasi

Abstract: Hockey's extracurricular activities are activities conducted outside of school hours provided by the school for the students of hockey game activities. Each troop will try to score a goal by using a crooked or curved wood at the end of the bat to steer a hard ball into the opposing goal. The purpose of this study is to determine the motivation of MTs students. Badrussalam Surabaya to the extracurricular activities of hockey sport. The benefits of research is to add knowledge about the motivation of MTs students. Badrussalam Surabaya to the extracurricular activities of hockey sport. This type of research uses qualitative descriptions. The subjects of the study were principal, student waka, BP teacher, teacher of pemas and 40 MTs students. Badrussalam Surabaya. Technique of collecting data of this research is observation by interview and documentation. The result of this research is that the motivation of MTs students. Badrussalam Surabaya in following the extracurricular sport of hockey is student interest, student motivation, student discipline and spirit of student to follow extracurricular sport hockey and support from school side.

Keyword: extracurricular hockey sport, motivation

\section{PENDAHULUAN}

Menurut Helen Ten M. Pheridas dalam Imam Syafi'I (2007: 13) menjelaskan: hockey merupakan sejenis sukon yang memerlukan kepantasan dan ketahanan yang dimainkan dalam sebuah padang rumput segi bujur sangkar, antara dua pasukan yang mengandung 11 pemain sepasukan. Setiap pasukan akan coba menjaringkan gol dengan menggunakan sebatang kayu yang bengkok atau berlekuk di ujung pemukul (with a crook at the hitting end) untuk mengarahkan sebiji bola yang keras ke dalam gol lawan.

Kegiatan ekstrakurikuler hockey merupakan kegiatan yang dilakukan di luar jam sekolah yang disediakan sekolah bagi para siswa kegiatan permainan hockey. Pada dasarnya kegiatan ekstrakurikuler hockey di sekolah MTs. Badrussalam Surabaya merupakan kegiatan yang tidak dapat dipisahkan dalam proses pendidikan siswa 
secara keseluruhan. MTs. Badrussalam Surabaya satu-satunya sekolah yang ada di Surabaya pada umumnya dan Surabaya pada khususnya yang mempunyai kegiatan ekstrakurikuler olahraga bockey. Kegiatan ini dapat terwujud dengan adanya interaksi antara siswa dan guru yang selalu memberikan dorongan, bimbingan dan pengembangan keterampilan untuk meningkatkan kreativitas dan aktivitas siswa dalam upaya mencapai tujuan kegiatan ekstrakurikuler olahraga hockey di MTs. Badrussalam Surabaya.

Kegiatan ekstrakurikuler hockey yang ada di MTs. Badrussalam Surabaya atas harus didukung penuh oleh pihak sekolah, siswa bebas memilih dan mengikuti jenis cabang olahraga yang sesuai dengan bakat dan minatnya, sehingga siswa dapat mengembangkan potensi yang ada pada setiap siswa. Selain itu perlu diberi pengarahan, dukungan dan bimbingan untuk mencapai hasil yang optimal. Kesimpulan bahwa kegiatan ekstrakurikuler hockey yang ada di MTs. Badrussalam Surabaya dapat memberikan kesempatan kepada siswa untuk mengembangkan bakat dan minat siswa dalam hal teknik dalam bermain hockey pembekalan bermain hockey itu diarahkan untuk membina sekaligus membentuk pemain dan menciptakan pemain yang berbakat dan berprestasi. Tujuan kegiatan olahraga bockey ini adalah untuk memajukan prestasi serta mengembangkan diri siswa agar tidak jenuh dalam belajar setiap hari di sekolah. Ada juga yaitu untuk melatih mental siswa-siswi.

Ekstrakurikuler di MTs. Badrussalam Surabaya antara hockey, pencak silat, dan drum band. Dari ketiga ekstrakurikuler tersebut, yang paling diminati siswa adalah hockey. Pelaksanaan ekstrakurikuler olahraga hockey, masih ada hambatan untuk latihan. Hambatannya terletak pada sarana dan prasarana yang ada di sekolah tersebut. Sekolah itu tidak mempunyai lapangan bockey.
Suatu saat pelatih hockey dari MTs. Badrussalam Surabaya mempunyai ide alternatif dengan mengajak siswanya latihan di lapangan hockey Unesa. Latihan ini dilaksanakan pada Minggu setiap pukul 06.00 WIB sampai pukul 08.00 WIB. Walaupun jarak sekolah ke lapangan hockey Unesa jauh, tetapi mereka antusias sekali melaksanakan kegiatan ini. Mereka mempunyai antusias sekali melaksanakan kegiatan ini. Siswa mempunyai motivasi yang tinggi untuk datang ke lapangan hockey Unesa dengan menggunakan sepeda. Sekitar 40 siswa yang mengikuti ekstrakurikuler ini. Di antaranya dari dua kelas, yaitu kelas I dan kelas II. Tidak hanya laki-laki saja yang semangat mengikuti ekstrakurikuler ini. Dari penjelasan latar belakang di atas, peneliti akan melakukan penelitian analisis motivasi siswa MTs. Badrussalam Surabaya terhadap kegiatan ekstrakurikuler olahraga hockey. Rumusan masalah penelitian ini adalah bagaimana motivasi siswa MTs. Badrussalam Surabaya terhadap kegiatan ekstrakurikuler olahraga hockey. Tujuan penelitian ini adalah untuk mengetahui motivasi siswa MTs. Badrussalam Surabaya terhadap kegiatan ekstrakurikuler olahraga hockey. Manfaat penelitian adalah dapat menambahkan pengetahuan tentang motivasi siswa MTs. Badrussalam Surabaya terhadap kegiatan ekstrakurikuler olahraga hockey. Keterbatasan penelitian ini adalah lokasi yang digunakan adalah MTs. Badrussalam Surabaya, ekstrakurikuler olahraga yang digunakan adalah olahraga hockey. Subjek penelitian adalah kepala sekolah, waka kesiswaan, guru BP, guru penjas MTs. Badrussalam Surabaya.

\section{METODE PENELITIAN}

Jenis Penelitian ini menggunakan deskripsi kualitatif. Metode kualitatif adalah sebagai prosedur penelitian yang menghasilkan data deskriptif yang merupakan kata-kata tertulis atau lisan 
dari orang-orang dan perilaku yang dapat diamati. Menurut mereka, pendekatan ini diarahkan pada individu tersebut secara utuh.

Teknik pengumpulan data dalam penelitian ini untuk bisa valid, maka perlu digunakan teknik yang dianggap sesuai dengan desain yang telah direncanakan, teknik tersebut antara lain: observasi dengan wawancara dan dokumentasi.

Proses analisis data dimulai dengan menelaah seluruh data yang tersedia dari berbagai sumber yaitu dari wawancara pengamatan yang sudah dituliskan dalam catatan lapangan dokumentasi, gambar, foto dan sebagainya (Moleong J.L. 2006: 157).

Bagdan menyatakan dalam buku (Sugiyono, 2008: 88) menyatakan analisis data adalah proses mencari dan menyusun secara sistematis data yang diperoleh dari hasil wawancara, catatan lapangan, dan bahan-bahan lain, sehingga dapat mudah, di pahami, dan temuannya dapat di informasikan kepada orang lain, analisis data dilakukan dengan mengorganisasikan data, menjabarkan ke dalam unit-unit, menyusun ke dalam pola, memilih mana yang penting dan yang akan dipelajari dan membuat kesimpulan yang dapat diceritakan kepada lain.

Tahap-tahap yang ditempuh dalam menganalisis data adalah merekam hasil dari responden lalu data dituangkan atau disalin dalam bentuk tulisan. Selanjutnya melakukan proses pemikiran secara mendalam, kemudian dari semua hasil responden tersebut disimpulkan.

\section{HASIL DAN PEMBAHASAN}

Hasil data wawancara bahwa motivasi siswa MTs. Badrussalam Surabaya dalam mengikuti ekstrakurikuler olahraga hockey menurut kepala sekolah, waka kesiswaan, guru BP dan guru penjas. Secara berturut-turut akan diuraikan tentang pendapat tentang motivasi siswa MTs. Badrussalam Surabaya dalam mengikuti ekstrakurikuler olahraga hockey sebagai berikut.

1. Menurut kepala sekolah MTs. Badrussalam Surabaya berpendapat bahwa motivasi siswa MTs. Badrussalam Surabaya yang memengaruhi adalah minat siswa, pihak sekolah dan orang tua siswa.

2. Menurut waka kesiswaan MTs. Badrussalam Surabaya berpendapat bahwa motivasi siswa yang memengaruhi adalah motivasi siswa itu sendiri yang tinggi dan memang olahraga hockey ini juga baru di MTs. Badrussalam Surabaya.

3. Menurut guru BP MTs. Badrussalam Surabaya berpendapat bahwa motivasi siswa yang memengaruhi adalah ada motivasi untuk belajar dan mempunyai semangat siswa yang tinggi.

4. Menurut guru penjas MTs. Badrussalam Surabaya berpendapat bahwa motivasi siswa yang memengaruhi adalah semangat siswa yang tinggi dan mempunyai mental dan disiplin.

Dari analisis data menunjukkan bahwa motivasi siswa MTs. Badrussalam Surabaya dalam mengikuti ekstrakurikuler olahraga bockey adalah mempunyai motivasi tinggi semangat dari siswa itu sendiri, pihak sekolah, orang tua, siswa serta mempunyai mental dan disiplin tinggi.

\section{SIMPULAN DAN SARAN}

\section{Simpulan}

Berdasarkan hasil analisis dan pembahasan tentang motivasi siswa MTs. Badrussalam Surabaya dalam mengikuti ekstrakurikuler olahraga hockey dikatakan aktif dan maju berkat dukungan dari semua pihak baik itu dari guru. 
Selain itu, motivasi yang paling mendukung adalah dari siswa itu sendiri karena siswa sangat berminat, motivasi yang tinggi untuk mengikuti kegiatan ekstrakurikuler olahraga hockey.

Uraian yang sebelumnya merupakan penjabaran dari hasil jawaban wawancara kepada kepala sekolah, waka kesiswaan, guru BP, guru penjas. Dengan begitu dapat diambil kesimpulan bahwa motivasi siswa MTs. Badrussalam Surabaya terhadap kegiatan ekstrakurikuler olahraga hockey adalah minat siswa, motivasi siswa, kedisiplinan, jujur, tangguh siswa dan semangat siswa untuk mengikuti ekstrakurikuler olahraga hockey serta dukungan dari pihak sekolah.

\section{Saran}

Pada bagian akhir ini berdasarkan simpulan yang telah disebutkan di atas, maka dalam upaya mengembangkan dan menunjukkan olahraga bockey di MTs. Badrussalam Surabaya maka dapatlah dikemukakan sejumlah saran sebagai berikut.

1. Untuk dapat lebih motivasi siswa MTs. Badrussalam Surabaya dalam mengikuti ekstrakurikuler olahraga hockey, perlu membeli alat-alat hockey yang akan mendukung kegiatan ekstrakurikuler olahraga hockey yang akan meningkatkan latihan dan prestasi olahraga di sekolah.

2. Sekolah diharapkan tahun depan bisa membeli alat tersebut dengan menganggarkan dana dari lembaga sekolah tersebut.

3. Kepala sekolah sebagai penanggung jawab harus selalu mendukung terutama dalam hal financial (dana) dan izin untuk mengikuti kejuaraan.

4. Semua pihak sekolah harus lebih mendukung lagi kegiatan yang dilakukan oleh ekstrakurikuler olahraga hockey
5. Kepada peneliti lain, penulis menyarankan menjadikan penelitian lebih lanjut tentang motivasi siswa MTs. Badrussalam Surabaya dalam mengikuti olahraga hockey. Karena penelitian ini masih banyak kekurangan dan kelemahan yang perlu disempurnakan lagi.

\section{DAFTAR RUJUKAN}

Brian, C. 2006. Instant Motivation. Jakarta: PT Gelora Aksara Pratama.

Desi P. 2009. Motivasi Pelajaran yang Mengikuti Olahraga Bela Diri Taekwondo di Club Taekwondo Lidah Wetan Surabaya. Skripsi tidak di publikasikan. Surabaya: Unesa.

Gunarsa, S.D. 2004. Psikologi Olahraga. Jakarta: PT BPK Gunung Media.

Maksum, A. 2006. Metodologi Penelitian dalam Olahraga. Surabaya: Fakultas Ilmu Keolahragaan Unesa.

Maksum, A. 2007. Psikologi Olahraga. Surabaya: Fakultas Ilmu Keolahragaan Unesa.

Moleong, J.L. 2006. Metodologi Penelitian Kualitatif. Bandung: PT Remaja Rosdakarya.

Oemar, H. 2005. Proses Belajar Mengajar. Jakarta: PT Bumi Aksara.

Slameto, 2003. Belajar dan Faktor-Faktor yang Mempengarubinya. Cetakan Keempat. Jakarta: PT RINEKA CIPTA.

Subyantoro A. dan Suwarto F.X. 2007. Metode dan Teknik Penelitian Sosial. Yogyakarta: CV Andy Offset.

Sugiyono. 2008. Memahami Penelitian Kualitatif. Bandung: CV ALFABETA. Anggota Ikatan Penerbit Indonesia (IKAPI).

Syafi'i, I. 2007. Faktor-faktor Pendukung Keberhasilan Ekstrakurikuler Olahraga Hockey di SMA Negeri 1 Kwanyar Bangkalan. Skripsi Tidak Dipublikasikan. Surabaya: Unesa. 